\title{
Nuclear Criticality Project Plan for the Hanford Site Tank Farms
}

\author{
D. R. Bratzel
}

A. C. Lilly

Date Published

April 1996

Prepared for the U.S. Department of Energy

Assistant Secretary for Environmental Management

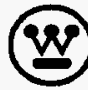

Management and Operations Contractor for the

U.S. Department of Energy under Contract DE-AC06-87RL.10930

Approved for public release; distribution is unlimited 


\section{RELEASE AUTHORIZATION}

Document Number: WHC-EP-0902, Rev. 0

Document Title: $\quad$ Nuclear Criticality Project Plan for the Hanford Site Tank Farms

Release Date: $\quad 8 / 6 / 96$

This document was reviewed following the procedures described in WHC-CM-3-4 and is:

APPROVED FOR PUBLIC RELEASE

WHC Information Release Administration Specialist:

$=$ A




\section{Nuclear Criticality Project Plan for the Hanford Site Tank Farms}

D. R. Bratzel

A. C. Lilly

Date Published

April 1996

Prepared for the U.S. Department of Energy

Assistant Secretary for Environmental Management

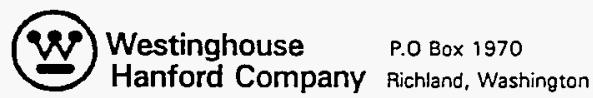

Menagement and Operations Contractor for the

U.S. Department of Energy under Contract DE-ACO5.87RL 10930

Approved for public release; distribution is unlimited 
NUCLEAR CRITICALITY PROJECT PLAN FOR THE HANFORD SITE TANK FARMS

Westinghouse Hanford Company Approvals:

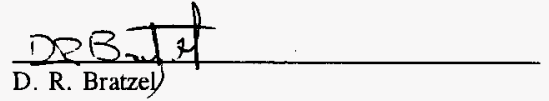

U.S. Department of Energy, Richland Operations Office Approval:

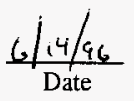

$\frac{8 / 1 / 96}{\text { Date }}$ 
WHC-EP-0902

Revision 0

This page intentionally left blank. 
WHC-EP-0902

Revision 0

CONTENTS

1.0 MISSION NEED/OBJECTIVES $\ldots \ldots \ldots \ldots \ldots \ldots \ldots \ldots \ldots \ldots \ldots \ldots \ldots$. $\ldots \ldots \ldots$

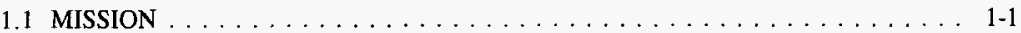

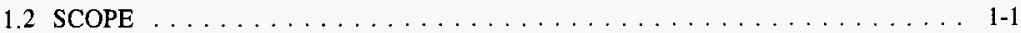

1.3 DEFINITION OF THE NUCLEAR CRITICALITY SAFETY ISSUE $\ldots \ldots \ldots \ldots$. . .

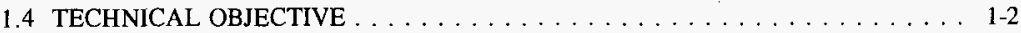

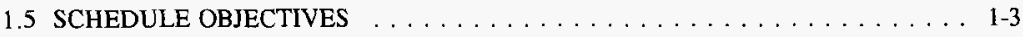

2.0 STRATEGY AND TECHNICAL PLAN $\ldots \ldots \ldots \ldots \ldots \ldots \ldots \ldots \ldots \ldots \ldots . \ldots \ldots$

2.1 STRATEGY AND LOGIC FOR RESOLUTION OF THE SAFETY ISSUE $\ldots \ldots$ 2-1

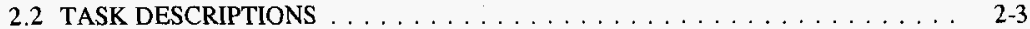

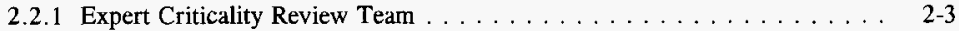

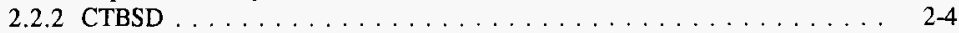

2.2 .3 Mechanistic Studies/Modeling . . . . . . . . . . . . . . . . 2-4

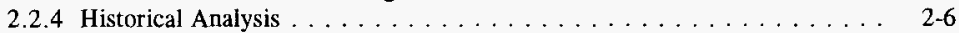

2.2 .5 Neutronics Analysis . . . . . . . . . . . . . . 2-7

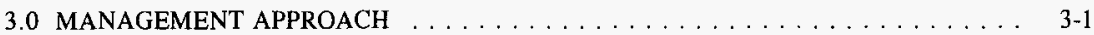

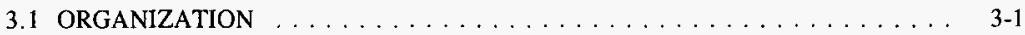

3.1.1 WHC Tank Waste Remediation System (TWRS) Criticality Safety Team . . 3-1

3.1 .2 Expert Criticality Review Team . . . . . . . . . . . . . . . . . . 3-1

3.1 .3 CTBSD Team . . . . . . . . . . . . . . . . . . . . 3-1

3.1.4 WHC Tank Waste Remediation System Projects Organization . . . . . . . 3-3

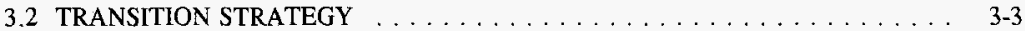

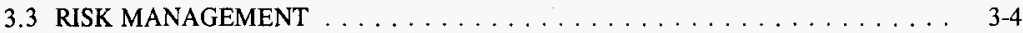

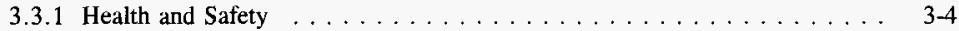

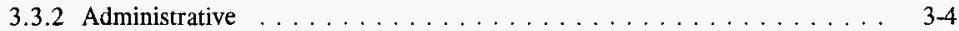

4.0 SCHEDULE . . . . . . . . . . . . . . . . . . . . $4-1$

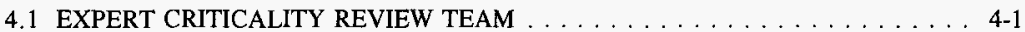

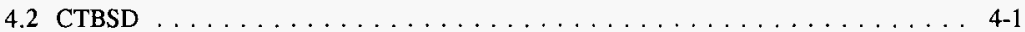

4.2.1 Mechanistic Studies/Modeling . . . . . . . . . . . . . . . 4-1

4.2 .2 Historical Review . . . . . . . . . . . . . . . . . . . 4-1

4.2 .3 Neutronics Analysis . . . . . . . . . . . . . . . 4-1

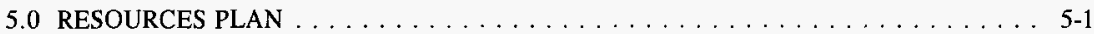

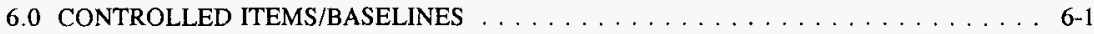

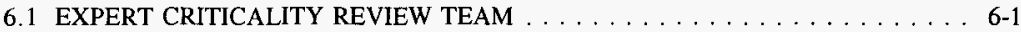

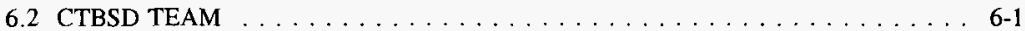

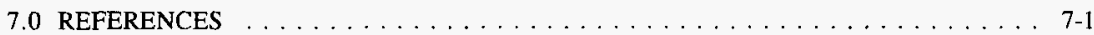

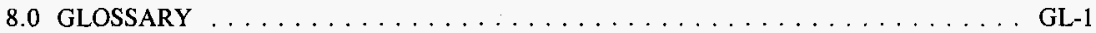

\section{LIST OF FIGURES}


WHC-EP-0902

Revision 0

1-1 Level I Schedule . . . . . . . . . . . . . . . . . . . . . . 1-4

$2-1$ Criticality Safety Issue Resolution Logic . . . . . . . . . . . . . . . . . 2-2

3-1 Westinghouse Hanford Company Tank Waste Remediation System

Criticality Safety Team . . . . . . . . . . . . . . . . . . . . 3-2

4-1 Schedule for Waste Partitioning and Distribution $\ldots \ldots \ldots \ldots \ldots \ldots \ldots \ldots$

4-2 Schedule for Historical Review/Analysis $\ldots \ldots \ldots \ldots \ldots \ldots \ldots \ldots$

4-3 Schedule for Neutronics Analysis $\ldots \ldots \ldots \ldots \ldots \ldots \ldots \ldots \ldots \ldots$ 
WHC-EP-0902

Revision 0

\section{NUCLEAR CRITICALITY PROJECT PLAN FOR THE HANFORD SITE TANK FARMS}

\subsection{MISSION NEED/OBJECTIVES}

\subsection{MISSION}

The mission of this project is to provide a defensible technical basis report in support of the Final Safety Analysis Report (FSAR). This technical basis report will also be used to resolve technical issues associated with the nuclear criticality safety issue. The strategy presented in this project plan includes an integrated programmatic and organizational approach.

\subsection{SCOPE}

The scope of this project plan includes the provision of a criticality technical basis supporting document (CTBSD) to support the FSAR as well as for resolution of the nuclear criticality safety issue. Specifically, the CTBSD provides the requisite technical analysis to support the FSAR hazard and accident analysis as well as for the determination of the required FSAR limits and controls.

The scope of the CTBSD will provide a baseline for understanding waste partitioning and distribution phenomena and mechanistics for current operational activities (i.e., "safe storage") inclusive of single-shell tanks, double-shell tanks, double-contained receiver tanks, and miscellaneous underground storage tanks. Although the FSAR does not include future operational activities (retrieval or pretreatment), the waste partitioning and distribution phenomena and mechanistics work scope identified in this project plan provide a sound technical basis as a point of departure to support independent safety analyses for future activities.

The CTBSD also provides the technical basis for resolution of the technical issues associated with the nuclear criticality safety issue. In addition to the CTBSD, additional documentation will be required to fully resolve U.S. Department of Energy-Headquarters (DOE-HQ) issues (e.g., administrative and programmatic issues). The strategy and activities defined in this project plan provide a CTBSD for the FSAR and for accelerated resolution of the safety issue in FY 1996.

\subsection{DEFINITION OF THE NUCLEAR CRITICALITY SAFETY ISSUE}

On April 30, 1992, a plant review committee reviewed the Final Safety Analysis Reports (FSARs) for the single-shell, double-shell, and aging waste tanks in light of the conclusions of the inadequate waste characterization with respect to fissile material. The review indicated that the conclusion in the FSARs, that a criticality is "not credible," cannot be supported for a full range of potential tank constituents. Therefore, a USQ was declared.

Development of a credible scenario leading to a criticality proved to be extremely difficult, given the paucity of data on the quantity and distribution of fissile material in the tanks. However, based on the study of process data from the waste generating facilities over past years, waste chemistry, and the samples of waste that were available, it was possible to establish that the waste in 
the tanks was subcritical by a large margin (Braun et al. 1994). This assessment applied to continued storage, but provides guidance for future tank farm allowed operations.

After extensive review, the Assistant Secretary for Environmental Restoration and Waste Management approved closure of the USQ in March 1994. The letter also indicated that a safety issue remained.

The nuclear criticality safety issue is defined as follows (Antizzo 1995):

". . . the lack of definitive knowledge of the fissile and absorber material inventory and distribution in the high-level waste (HLW) tanks. The HLW tanks include Double Shell Tanks (DSTs), Single Shell Tanks (SSTs), Double Contained Receiver Tanks (DCRTs), and Catch Tanks. The Miscellaneous Underground Storage Tanks (MUSTs) are not included in this safety issue." The letter reiterated, "While the USQ closure provided a high degree of confidence in the present subcriticality of the Hanford tanks, it could not resolve the central cause of the safety issue: uncertainties in the fissile and absorber materials inventories and distributions in the tanks which could conceivably affect the safety of present, as well as future, operations."

By definition of the safety issue, obtaining additional empirical data (i.e., tank waste characterization) is implied to provide more definitive knowledge of the fissile and absorber material inventory and distribution. Although this project plan defines additional technical work scope to quantify the fissile and absorber material inventory, the Hanford Site Safety and Characterization Programs have demonstrated that focusing on gaining detailed empirical data of the waste tank contents (i.e., extensive characterization) is neither technically practical or cost-effective.

The approach defined in this project plan provides a technically defensible strategy based on recommendations from a DOE-HQ criticality review team and an independent expert criticality review team to ensure subcriticality in the waste tanks. The neutronic behavior of the tanks is well known, and the tanks have been shown to be substantially subcritical at the present time. The current strategy is based on added technical understanding of chemical, physical, and mechanistic phenomena (e.g., waste partitioning and distribution). This approach provides a defensible technical basis and costeffective approach in support of the FSAR and for resolution of the nuclear criticality safety issue in lieu of the existing uncertainty of fissile material inventory and distribution.

In addition, the Hanford Federal Facility Agreement and Consent Order (Tri-Party Agreement) (Ecology et al. 1994) Milestone M-40-12 is defined as follows: "Resolve Nuclear Criticality Safety Issue" (due 09/99).

\subsection{TECHNICAL OBJECTIVE}

The objective of this project plan is to develop a strategy and technical approach to provide a CTBSD for the FSAR and for resolution of the nuclear criticality safety issue pertaining to tank farm waste storage and transfer operations. The strategy and technical approach identified in this project plan include definition of administrative and technical tasks. Technical analyses will include mechanistic studies (i.e., waste partitioning and distribution), historical data review, and additional limited neutronics analysis. Completion of these studies will be documented in a CTBSD to support the existing criticality technical basis (Braun et al. 1994; Vail 1994a and 1994b; Rogers 1994a and 1994b). The CTBSD will be incorporated in the criticality portion of the FSAR. 
WHC-EP-0902

Revision 0

\subsection{SCHEDULE OBJECTIVES}

The Level I schedule to support the FSAR and for resolution of the criticality safety issue is depicted in Figure 1-1. The schedule is based on completing defined technical studies to provide a defensible CTBSD to support past conclusions that "a large margin of subcriticality for the Hanford Site high-level waste tanks was demonstrated" (Braun et al. 1994). The CTBSD will provide adequate technical justification in support of the FSAR and for resolution of technical concerns associated with the nuclear criticality safety issue. Consistent with Authorization Basis approval authority by the U.S. Department of Energy, Richland Operations Office (RL) (Wagoner 1995), approval for resolution of the nuclear criticality safety issue will be provided by RL upon completion of the CTBSD. 
Figure 1-1

MANAGE TANK WASTE -- CRITICALITY

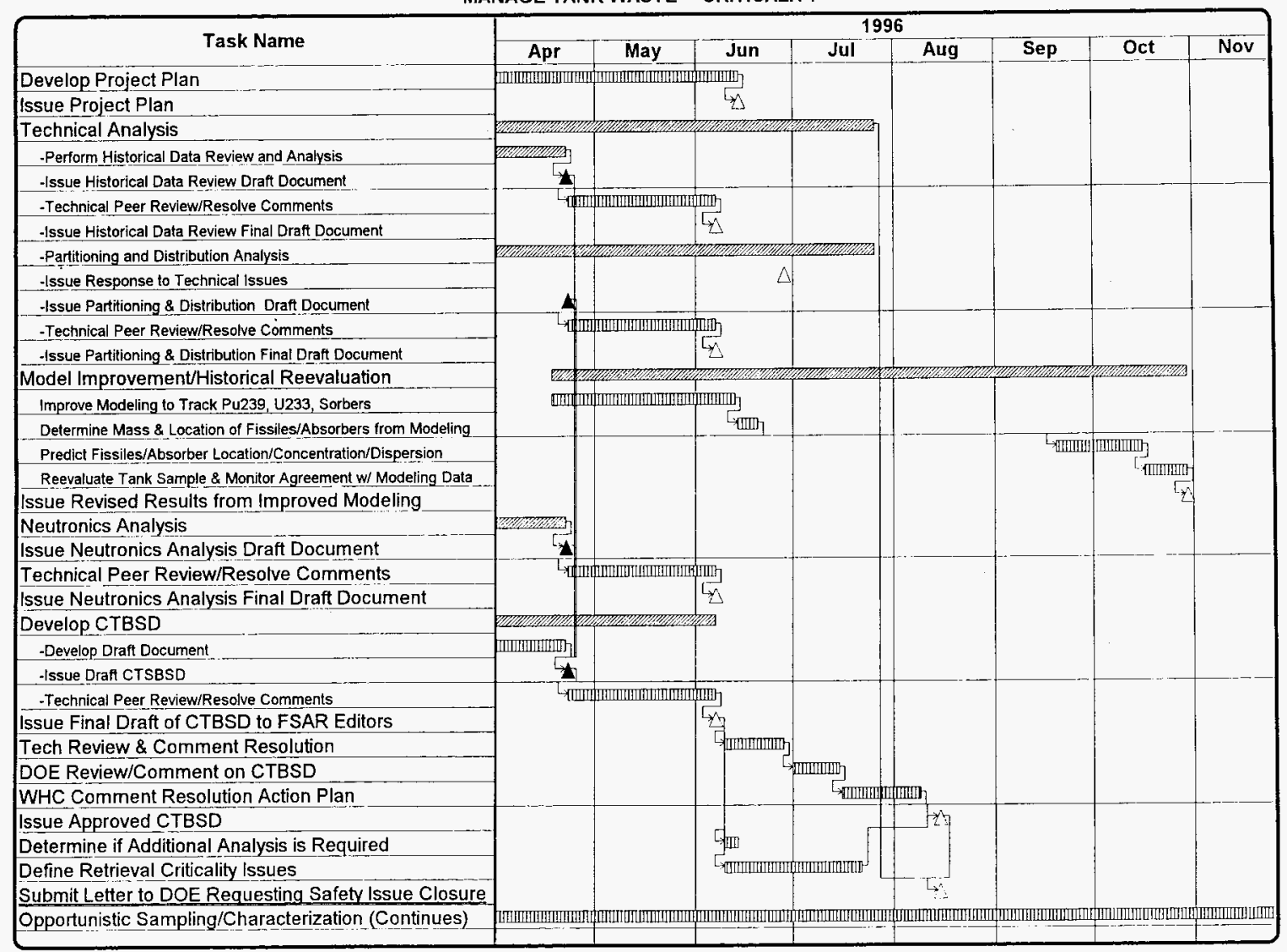




\subsection{STRATEgY AND TECHNICAL PLAN}

\subsection{STRATEGY AND LOGIC FOR RESOLUTION OF THE SAFETY ISSUE}

A strategy and technical approach have been developed to support the FSAR and for resolution of the nuclear criticality safety issue as a result of recommendations proposed by the recently established expert criticality review team. The strategy is based on past recommendations from technical reviews as well as from previously established issue resolution logic (Vail 1992). The strategy identified within this project plan is based on a comprehensive and integrated technical approach to include the strong neutronics technical basis previously established (Braun et al. 1994; Vail 1994a and 1994b; Rogers 1994a and 1994b), as well as additional work scope to evaluate mechanistic phenomena associated with waste tank chemistry and physics. In addition, the work scope identified within this project plan includes additional historical data analysis and limited additional neutronics analysis. The output of this work scope will be a technical document to provide a defensible technical basis to support the FSAR and for resolution of the nuclear criticality safety issue. The administrative and technical activities required to support this project are depicted in Figure 2-1 and described in Section 2.2.

The logic basis for pursuing resolution of the nuclear criticality safety issue is based on the following:

\section{Problem Definition}

- Define problem.

- Develop a defensible technical basis for satety issue resolution.

- Develop manageable criteria to ensure subcriticality.

\section{$\underline{\text { Tank Operations }}$}

- Ensure tanks are within the criteria.

- Operate within an approved Authorization Basis.

Tank Operations--The CTBSD will be the primary deliverable of this project plan, and it will provide a defensible technical basis to support the FSAR and resolution of the nuclear criticality safety issue. The nuclear criticality safety issue will be resolved upon completion of the CTBSD assuming that the tank contents are within the established limits and controls. If tank conditions are outside the established limits and controls, additional analysis, or possibly mitigation, may be required to resolve the nuclear criticality safety issue.

The Westinghouse Hanford Company (WHC) maintains the Hanford Site waste tanks in a safe condition in accordance with the approved Authorization Basis. Following resolution of the safety issue, an adequate margin of safety for continued waste storage and selected future operations will be controlled through criticality limits and controls to an approved Authorization Basis. 


\section{WHC-EP-0902}

Revision $\mathrm{C}$

Figure 2-1. Criticality Safety Issue Resolution Logic.

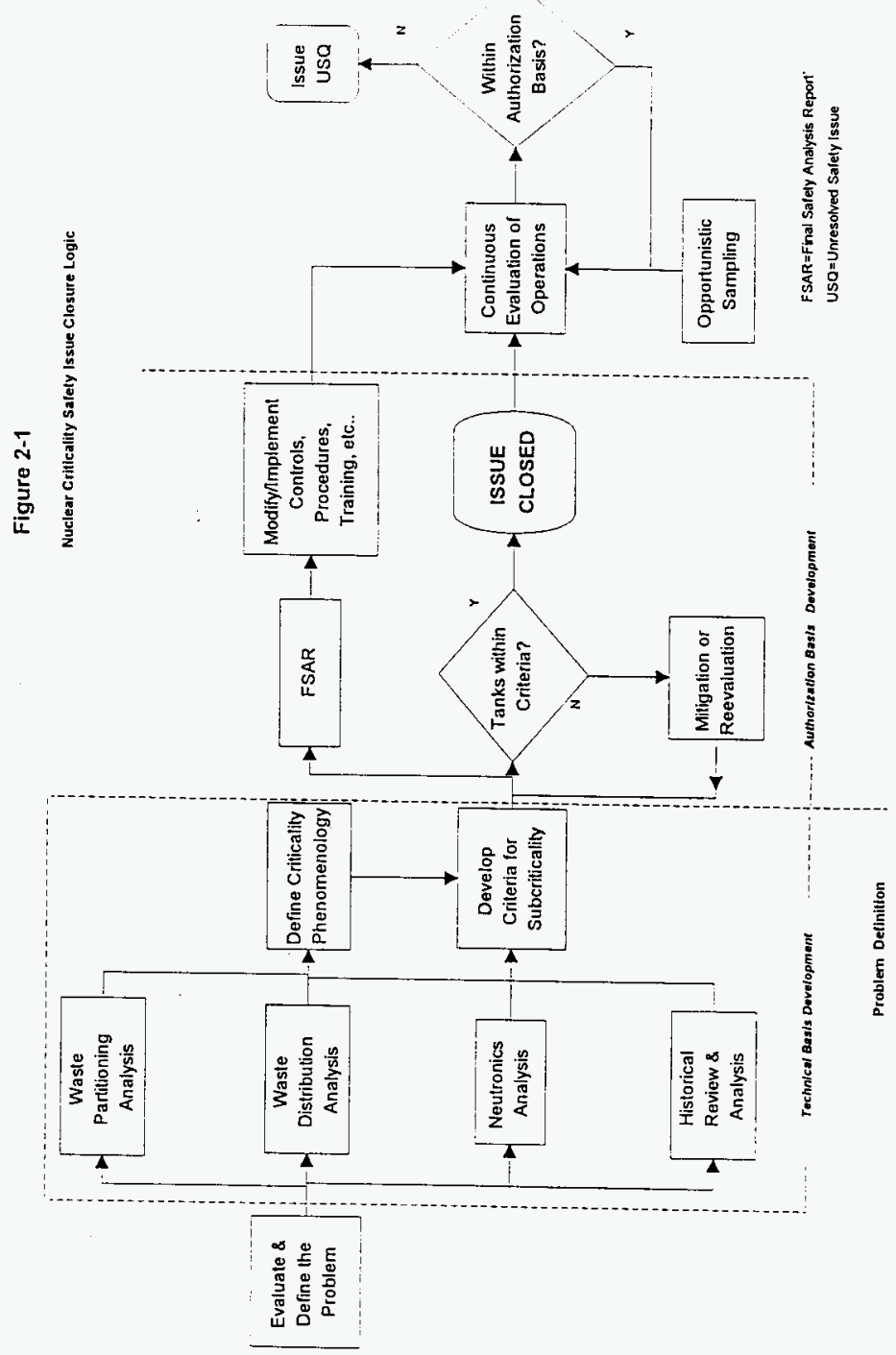


WHC-EP-0902

Revision 0

Westinghouse Hanford Company implements the operational limits and controls to maintain the Hanford Site waste tanks subcritical. Any proposed changes in the waste tanks or operations involving the waste tanks shall be evaluated via the Unreviewed Safety Question (USQ) process (DOE Order 5480.21) to determine if the proposed changes are within the Authorization Basis. If it is determined the proposed changes are outside of the Authorization Basis, a USQ will be declared and will require a modification to either the activity to bring it within the Authorization Basis, or a modification to the Authorization Basis defining the hazards and controls necessary to allow the proposed changes. Opportunistic sampling of the waste tank contents will continue to be provided through the Characterization Program (Hunt 1995). Characterization data will continue to be reviewed against the assumptions from which the safety basis is established.

\subsection{TASK DESCRIPTIONS}

The following sections describe the defined tasks that will be completed to support the CTBSD.

\subsubsection{Expert Criticality Review Team}

\section{Technical Approach}

An expert criticality review team has been established and comprises senior technical personnel (both contractor as well as U.S. Department of Energy [DOE] participants) whose expertise encompasses all appropriate aspects of criticality safety (scientific and engineering). The expert team will review the technical basis for the nuclear criticality safety of stored wastes at the Hanford Site Tank Farm Complex. The team will focus on the nucleonics-related studies underlying the criticality safety basis. Specifically, the team will review the criticality safety evaluation that establishes the criticality prevention specification limits and controls. This technical review will be documented to support the FSAR and resolution of the nuclear criticality satety issue. The review team also has been instrumental in defining the technical strategy defined in this project plan for resolution of the nuclear criticality safety issue. The technical strategy is structured around the following key elements.

- Provide technical justification for the nucleonics underlying the criticality safety basis.

- Provide technical knowledge to confirm mechanisms that would cause fissile materials to be dispersed throughout tank wastes.

- Evaluate the supporting evidence that a significant concentration of fissile species, once dispersed in the various waste forms, is not feasible.

\section{Schedule Basis and Deliverables}

The deliverable for this task is to develop a CTBSD, which will be submitted to the FSAR organization as a final draft in June 1996 for review and issuance. The expert team will continue to be maintained after issuance of the report to provide additional expert consultation. 
WHC-EP-0902

Revision 0

\subsubsection{CTBSD}

\section{Technical Approach}

The objective of the CTBSD will be to provide a defensible technical basis to support the FSAR and for resolution of the nuclear criticality safety issue in Hanford Site waste tanks. This document also will provide the technical basis to operate within a technically defensible Authorization Basis with respect to the criticality safety issue. The CTBSD will integrate all the technical tasks defined in this project plan to support the FSAR and for resolution of the nuclear criticality safety issue. The focus of these studies will include technical analysis of mechanistic studies (i.e., waste partitioning and distribution) as well as additional historical data review and supporting neutronics analysis. The CTBSD will integrate the data, evaluation, and summaries established by the other studies. The integration will support conclusions about the status of criticality safety concerns for current and some selected future operations. The scope of the technical studies will include conditions in the 149 single-shell waste tanks, 28 double-shell waste tanks, double-contained receiver tanks, and catch tanks at the Site. Finally, the CTBSD will provide a technical, defensible basis to revise nuclear criticality safety limits, if required.

\section{Schedule Basis and Deliverables}

The deliverable for this task is the CTBSD. A draft document will be issued to the FSAR organization on April 22 for peer review. Following comment resolution and incorporation, a final draft of the document will be resubmitted to the FSAR technical editors on June 7,1996 . The CTBSD will provide the technical basis and justification for resolution of the nuclear criticality safety issue. Any additional technical activities required to support the criticality program will be identified in the report. The schedule for the CTBSD is based on two important issues:

1. FSAR/Authorization Basis--The CTBSD provides the technical input for the FSAR to continue to safely operate waste tank activities within an approved Authorization Basis.

2. Criticality Safety Issue Resolution--The CTBSD provides the technical analysis for resolution of the nuclear criticality safety issue.

The technical tasks required to support the CTBSD are defined as follows.

\subsubsection{Mechanistic Studies/Modeling}

\section{Technical Approach}

The purpose of this task is to perform a technical analysis of physical and chemical processes (i.e., waste partitioning and distribution) and postulated scientific phenomena that may result in concentration or enrichment of fissile materials and/or neutron absorbers. The mechanistic studies are identified and defined in Subsections 2.2.3.1 and 2.2.3.2. 
WHC-EP-0902

Revision 0

Schedule Basis and Deliverables

The deliverables of this task include the following:

- A document describing the chemical and coupled chemical/physical mechanisms that can impact the fate, segregation, and stability of plutonium and neutron absorbers in Hanford Site tanks

- A letter report that addresses the technical issues previously identified by the DOE (Calley 1995)

- Input to a recommendations/priority document for future activities that would improve the knowledge base for defining the potential for criticality occurrences in Hanford Site tanks.

Schedule dates for deliverables are as follows:

Draft Document:

Final Draft Document to FSAR Editors:

Recommendations/priorities input:

Technical issues response letter:
April 22, 1996 (Completed)

June 7, 1996 . (Completed)

June 7, 1996 (Completed)

June 28, 1996. (Completed)

This document will be referenced by the CTBSD. The schedule for the waste partitioning analyses is based on providing input to meet the schedule of the CTBSD to support the FSAR.

The project work scope and funding for the waste partitioning and distribution activities are limited to technical analysis of the chemical/physical phenomena and mechanistics identified in Section 2.2.3.1 and 2.2.3.2. The work scope does not include resolution of technical concerns or issues requiring additional detailed study or funding (i.e., such as extensive laboratory experimentation to evaluate fissile material chemistry mechanisms or retrieval-specitic issues).

\subsubsection{Waste Partitioning Analysis (Chemistry).}

\section{Technical Approach}

This task will evaluate the chemistry of fissile and neutron absorber material under tank waste conditions to support the assessment of subcriticality in the waste tanks. The following chemical processes will be evaluated:

A. Precipitation/dissolution of discrete pure phases, solid solutions, and amorphous scavenged coprecipitates:

1. Hydrolysis ( $\mathrm{pH}$ effects)

2. Complexation (including inorganic and organic ligands)

3. Ionic strength

4. Redox state (oxidation-reduction)

5. Temperature

6. Radiolysis 
B. Adsorption-desorption of fissiles onto waste solids:

1. Initial state of main substrates

2. Substrate recrystallization/aging

3. $\mathrm{pH}$ effects

4. Complexation effects

5. Ionic strength effects

6. Oxidation-reduction effects

7. Temperature effects

8. Radiolysis effects.

C. Ore formation analogue--concentration of rare elements into localized areas.

\subsubsection{Waste Distribution Analysis (Physics).}

\section{Technical Approach}

This task will evaluate the mechanical processes that have been identified as proposed mechanisms which could promote segregation of discrete particles (i.e., concentration or enrichment of fissile materials). These mechanical processes will be evaluated in terms of the potential to create gradients which may potentially affect the identified tank operations:

A. Fluid dynamics--amount of energy needed to dislodge particles

B. Differential settling of particles during tank loading and intermittent additions

C. Differential settling of particles during cascading

D. Differential settling/redistribution caused by air-lift circulators

E. Differential redistribution caused by salt well pumping

F. Differential redistribution caused by jet nozzle mixer pumps

G. Differential redistribution caused by sluicing

H. Physical impacts of aging (densification)

I. Temperature effects (convection cells)

J. Ore purification analogue (e.g., gold placer mining/froth flotation).

\subsubsection{Historical Analysis}

\section{Technical Approach}

The objective of this task is to provide a quantitative historical account of fissile and neutron absorber materials in the Hanford Site tank wastes. Uncertainty determinations for fissile and absorber materials will be calculated, where possible, and outstanding issues will be identified. This task will evaluate the effects of incomplete waste transfer records, total transfer traffic among waste tanks, characterization results, and current understanding of waste composition variability. A limited comparison of tank characterization results against the historical tank waste model will be performed where data are available. This comparison will enable ranking of all tanks with regard to which tanks pose the greatest potential uncertainty, refinement of characterization screening criteria, and tank modeling and characterization guidance. The results will be used to support the CTBSD in support of the FSAR and for resolution of the nuclear criticality safety issue. 
$\underline{\text { Schedule Basis and Deliverables }}$

The deliverable for this task will be a document of the best available data indicating the mass of fissile and absorber material in the Hanford Site waste tanks. In addition, a determination of the uncertainty of these data will be provided in the report. This document will be referenced by the CTBSD and is dependent on supporting the CTBSD completion schedule.

Schedule dates for deliverables are as follows:

Draft Document:

April 22, 1996

(Completed)

Final Draft Document to FSAR Editors:

June 7, 1996

(Completed)

\subsubsection{Neutronics Analysis}

\section{Technical Approach}

The objective of this task is to provide additional supporting neutronics analysis relevant to criticality safety of the Hanford Site waste tanks. To date, a significant effort has been completed to evaluate the neutronics of the waste, and has provided the requisite calculations to establish criticality limits and controls (Braun et al. 1994; Vail 1994a and 1994b; Rogers 1994a and 1994b). Therefore, minimal additional calculations or analysis will be required to support the FSAR and for resolution of the nuclear criticality safety issue. The focus of this task will include bounding neutronic and graphic computer results to support the FSAR.

\section{$\underline{\text { Schedule Basis and Deliverables }}$}

The primary deliverable for this activity will include providing a document of the bounding neutronics and graphics to support the FSAR and for resolution of the nuclear criticality safety issue. This document will be referenced by the CTBSD and is dependent on supporting the CTBSD completion schedule.

Schedule dates for deliverables are as follows:

Draft Document:

Final Draft Document to FSAR Editors:
April 22, 1996

June 7, 1996
(Completed)

(Completed) 
WHC-EP-0902

Revision 0

This page intentionally left blank. 


\subsection{MANAGEMENT APPROACH}

To resolve the nuclear criticality safety issue, a matrix organization will be used. Figure 3-1 depicts the overall organization which will support resolution of the safety issue. This section of the project plan will discuss the responsibilities of each of the respective organizations. In addition, this section will discuss the organizational transition strategy for the long-term operation of the tank farms with respect to criticality safety.

\subsection{ORGANIZATION}

\subsubsection{WHC Tank Waste Remediation System (TWRS) Criticality Safety Team}

Figure 3-1 shows the overall team supporting resolution of the nuclear criticality safety issue. The organization and personnel assembled were selected to perform their respective tasks to ensure that the appropriate technical expertise and experience are applied to resolve all aspects of this safety issue. The TWRS Criticality Project Safety Team manager is responsible for managing the overall effort to resolve the nuclear criticality safety issue. This individual is responsible for managing the scope, schedule, and budget for the project as well as coordinating efforts of this matrixed organization. Responsibilities of each of the respective organization functions are identified as follows.

\subsubsection{Expert Criticality Review Team}

An expert criticality review team has been assembled for review of all aspects of the criticality safety issue. The members of the expert review team include contractor and DOE participants. The expert review team is responsible for reviewing the criticality technical basis as well as assessing the technical adequacy of the criticality specification limits and controls. Recommendations by the expert review team have been instrumental in establishing the strategy and approach identified in this project plan for resolution of the nuclear criticality safety issue.

In addition, the expert criticality review team has expanded its ongoing technical evaluations to include evaluation of the technical basis to proceed with the retrieval of waste from tank 241-C-106 (currently scheduled for the fall of 1996).

\subsubsection{CTBSD Team}

The organizations and responsibilities for supporting the CTBSD include the following.

CTBSD--The lead for this task will provide overall responsibility for the preparation of the CTBSD. This individual will be responsible for coordinating the technical activities required to support the FSAR and for resolution of the nuclear criticality safety issue. 


\section{WHC TWRS Criticality Safety Team}

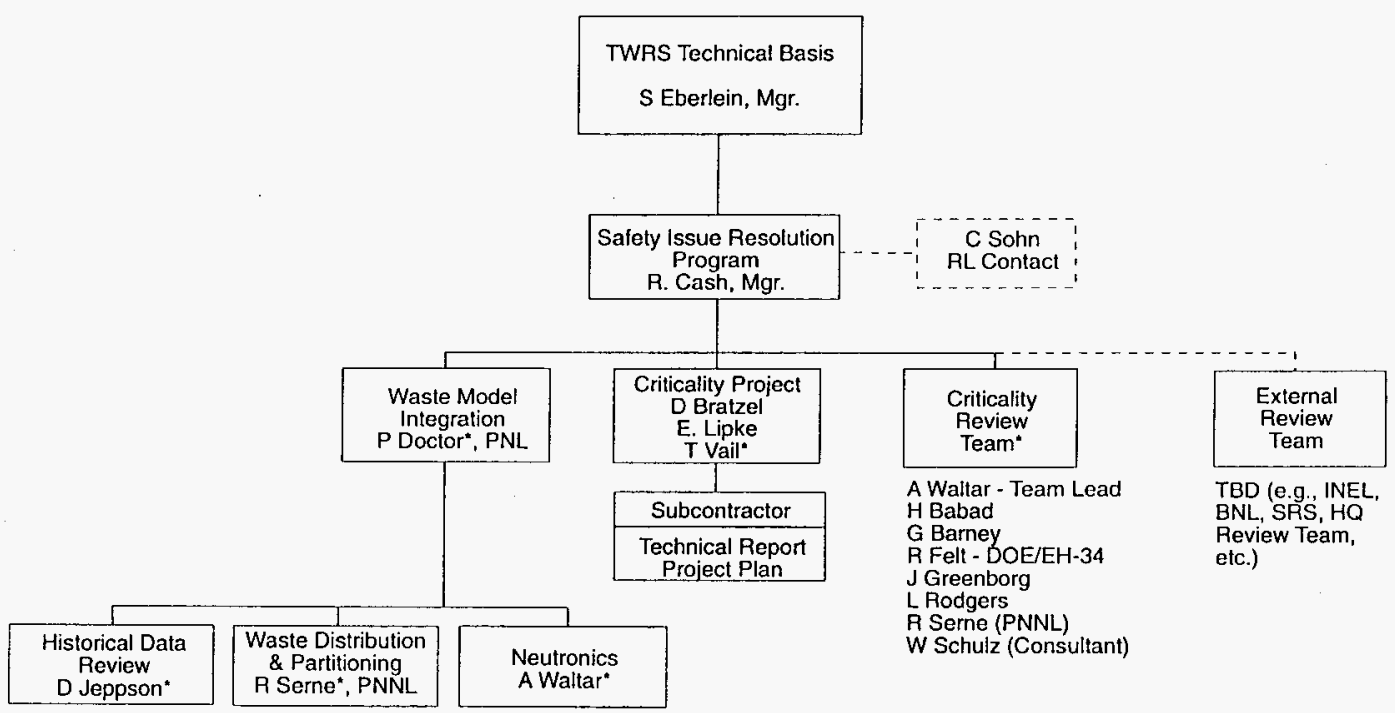

-Matrix Support (Individuals to be finalized) 
WHC-EP-0902

Revision 0

Waste Model Integration--Overall coordination of the efforts to establish the scientific basis for the mechanistic studies and evaluation of the historical data, is being coordinated by Pacific Northwest National Laboratory (PNNL). Additional responsibilities/organizations are as follows.

- The waste partitioning (chemistry) task is being performed by PNNL.

- The waste distribution (physics) task is being performed by PNNL.

- The historical analysis tasks are being performed by WHC. The evaluation of tank modeling results is being supported by PNNL.

- The neutronics task is being performed by the WHC criticality analysis organizations.

\subsubsection{WHC Tank Waste Remediation System Projects}

Westinghouse Hanford Company Tank Waste Remediation System (TWRS) Project organization implements the operational limits and controls to maintain the Hanford Site waste tanks subcritical. Any changes in the waste tanks or operations to the waste tanks that fall outside the developed controls and limits will be evaluated to ensure that the change does not invalidate the assumptions of the Authorization Basis. Process changes beyond the assumptions of the Authorization Basis must be analyzed, reviewed, and approved with proper controls put in place before commencing the operation. The TWRS Remediation Projects organization has the following responsibilities with respect to nuclear criticality safety:

- Implementation of defined limits and controls

- Development of procedures implementing nuclear criticality safety requirements

- Training of personnel to the requirements

- Ensure operation of tanks within the Authorization Basis

- Periodic reassessment of tank subcriticality using all available waste characterization data through opportunistic sampling

- Mitigation, if required.

\subsection{TRANSITION STRATEGY}

Completion of the CTBSD will provide a defensible technical basis in support of the FSAR and for resolution of the safety issue. The CTBSD will provide the technical basis in support of the FSAR to develop the hazard and accident analysis as well in support of the consequence analysis (if required). The CTBSD will also support the FSAR review and determination of appropriate limits, controls and technical specification requirements (TSRs). It is the intent of the CTBSD to provide the technical basis for a seamless transition in support of these FSAR activities. These FSAR activities are outside of the scope and funding authorization identified by this specific project plan.

Following resolution of the nuclear criticality safety issue, nuclear criticality safety in the waste tanks will continue to receive appropriate attention to maintain the safety margin in the Authorization Basis. 
Opportunistic sampling for characterization and other purposes will provide results to evaluate against the technical basis assumptions to continue to ensure subcriticality of the waste tank contents. Future tank farm operations (e.g., waste transfer and retrieval) will continue to be controlled based on the established criticality limits and controls.

\subsection{RISK MANAGEMENT}

This section of the project plan addresses risk management relative to the nuclear criticality safety issue. Two elements of risk are involved with this safety issue: health and safety, and administrative. The first element of risk is the health and safety risk to the public, workers, and environment. The second element of risk is the administrative risk in regard to resolution of the nuclear criticality safety issue.

\subsubsection{Health and Safety}

The neutronics of the waste tanks are well known (Braun et al. 1994; Vail 1994a and 1994b; Rogers 1994a and 1994b), and the tanks have been shown to be substantially subcritical at the present time. The strategy presented in this project plan includes additional technical analyses to provide added technical understanding of chemical and mechanical phenomena. The expected outcome of the additional technical analyses is to confirm that the tanks will continue to remain subcritical inclusive of selected future operations.

Review of the existing criticality technical basis also has confirmed that the existing controls and limits are adequate to ensure continued safe operation of the tank farm facilities. The ongoing tank farm FSAR development also will evaluate the chemical and mechanistic results to identify whether additional controls and limits will be required.

Consistent with safety analysis requirements, however, a consequence analysis was performed to evaluate the effects of a criticality event in the tank farms (Hey 1993). The consequence analysis was based on the most conservative approach (i.e., assumed that the generated steam bubble would be released from the tank without restrictions to the onsite receptor). Even under this most conservative approach, the results of the consequence analysis were within acceptable guidelines.

In addition, a criticality consequence analysis will be performed as part of the ongoing FSAR development. The technical and mechanistic work scope identified in this project plan will be used to identify specitic pathways and/or mechanisms for a postulated event.

\subsubsection{Administrative}

Failure to approve the strategy and technical analysis work scope identified in this project plan will affect resolution of the nuclear criticality safety issue at the risk of increased future budget requirements which are currently not accounted for in the multi-year program plan. As identified in this project plan, the presented strategy provides for resolution of the safety issue within FY 1996 (noting a continuing operational program to ensure safe operation of the tank farms). To date, the resolution mechanism and responsibility for the nuclear criticality safety issue have not been adequately defined. This project plan provides the identified technical work scope for resolution of the nuclear criticality safety issue dependent upon RL approval consistent with Authorization Basis 


\section{WHC-EP-0902}

\section{Revision 0}

responsibility (Wagoner 1995). Failure to resolve the safety issue within FY 1996 will result in additional technical work scope and funding not currently identified in the multi-year program plan. The impact is not minimal based on consideration of the declining Hanford Site budget constraints. 
WHC-EP-0902

Revision 0

This page intentionally left blank. 
WHC-EP-0902

Revision 0

\subsection{SCHEDULE}

The overall schedule depicted in Figure 1-1 has been developed from detailed (Level II) schedule input from the following responsible organizations.

\subsection{EXPERT CRITICALITY REVIEW TEAM}

The criticality review team will provide input for the CTBSD. This report supports the overall technical direction for resolution of the nuclear criticality safety issue. The review team will be maintained on an "as needed" basis for follow-up criticality technical reviews.

\subsection{CTBSD}

The schedule for development of the CTBSD is based on completion of the technical studies to the extent that the report can be issued with sufficient backup and meet the schedule for development of the FSAR. Currently, the document is scheduled to be issued as a draft to the FSAR organization in June 1996 for review and issuance. The nuclear criticality safety issue cannot be resolved without development of a defensible technical basis to ensure subcriticality.

\subsubsection{Mechanistic Studies/Modeling}

The PNNL is performing the mechanistic studies/modeling task as previously discussed. The schedule for these activities supports the development of the CTBSD, resolution of technical issues documented in the "Calley Report" (Calley 1995), and development of the FSAR. Figure 4-1 depicts the detailed schedule for the activities supporting resolution of the nuclear criticality safety issue. The PNNL will issue a draft document to support the CTBSD and FSAR as shown in Figure 1-1. The document will identify any follow-up technical tasks. If required, this information will be factored into a revision of the CTBSD and the FSAR.

\subsubsection{Historical Review}

The detailed historical review schedule is depicted in Figure 4-2. The schedule is based on providing as much data and knowledge as possible in a time frame to support the development of the CTBSD. Review of classified records and all output of the waste partitioning and distribution studies will not be ready in time to complete modeling improvement before completion of the CTBSD. These activities will be performed later. Their impact will be evaluated upon their completion for update of the CTBSD and the FSAR, as necessary.

\subsubsection{Neutronics Analysis}

The neutronic summary analysis detailed schedule is depicted in Figure 4-3. The schedule is based on providing the criticality input to meet development of the CTBSD and the FSAR. Additional activities are likely to be added as additional scenarios are evaluated. 
Figure 4-1

PARTITIONING \& DISTRIBUTION

\begin{tabular}{|c|c|c|c|c|c|c|}
\hline \multirow{2}{*}{ Task Name } & \multicolumn{6}{|c|}{1996} \\
\hline & Feb & Mar & Apr & May & $\mathrm{Jun}^{-}$ & Jul \\
\hline \multirow{2}{*}{\multicolumn{7}{|c|}{$\begin{array}{l}\text { Review Material on Chem/Physical Processes \& Coupling Effects } \\
\text { Review Heat Exchange/Fluid Dynamic/Sediment Transport Codes }\end{array}$}} \\
\hline & 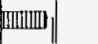 & & & & & \\
\hline \multicolumn{7}{|l|}{ List Processes \& Coupling Effects \& Assign Work } \\
\hline \multicolumn{7}{|l|}{ Crosswalk Issues with Processes } \\
\hline \multicolumn{7}{|l|}{ Analysis of State Knowledge vs Tank Criticality Technical Basis } \\
\hline \multicolumn{7}{|l|}{-Generate Waste Stream Information } \\
\hline \multicolumn{7}{|l|}{-Describe Chemical Composition of Selected Tanks } \\
\hline \multicolumn{7}{|l|}{-Perform Solubility Literature Analysis } \\
\hline \multicolumn{7}{|l|}{-Perform Adsorbtion/Desorption Literature Analysis } \\
\hline \multicolumn{7}{|l|}{-Perform Concentrating Mechanisms Literature Analysis } \\
\hline \multicolumn{7}{|l|}{-Fluid Dynamics Analysis } \\
\hline \multicolumn{7}{|l|}{ *Describe \& Prioritize Mechanical Processes } \\
\hline \multicolumn{7}{|l|}{${ }^{\star}$ Collate Input Data } \\
\hline \multicolumn{7}{|l|}{${ }^{*}$ Model (Simplified) } \\
\hline \multicolumn{7}{|l|}{-Develop Draft Document on Partitioning \& Distribution } \\
\hline \multicolumn{7}{|l|}{-Issue Draft Document on Partitioning \& Distribution } \\
\hline \multicolumn{7}{|l|}{-Technical Peer Review/Resolve Comments } \\
\hline \multicolumn{7}{|l|}{-Issue Final Draft Document } \\
\hline \multicolumn{7}{|l|}{ Build System Conceptual Model } \\
\hline Conceptual Model Documentation (Criticality Technical Basis) & & 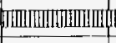 & Ulrim & 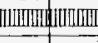 & ]idi] & \\
\hline \multicolumn{7}{|l|}{ Recommend/Prioritize Activities to Improve Knowledge } \\
\hline \multicolumn{7}{|l|}{ Bounding Calculations Report } \\
\hline \multicolumn{7}{|l|}{ Review/Comment/Reissue Bounding Calculations Report } \\
\hline \multicolumn{7}{|l|}{ Specific Response Document Organized by Issue } \\
\hline \multicolumn{7}{|l|}{ Issue Response to Technical Issues Raised By "Calley Letter" } \\
\hline \multicolumn{7}{|l|}{ Sophisticated Model (Coupled Chemistry \& Physics) } \\
\hline Clarification of Input to CTBSD \& FSAR & & & & & & \\
\hline
\end{tabular}


Figure 4-2

HISTORICAL REVIEW \& ANALYSIS

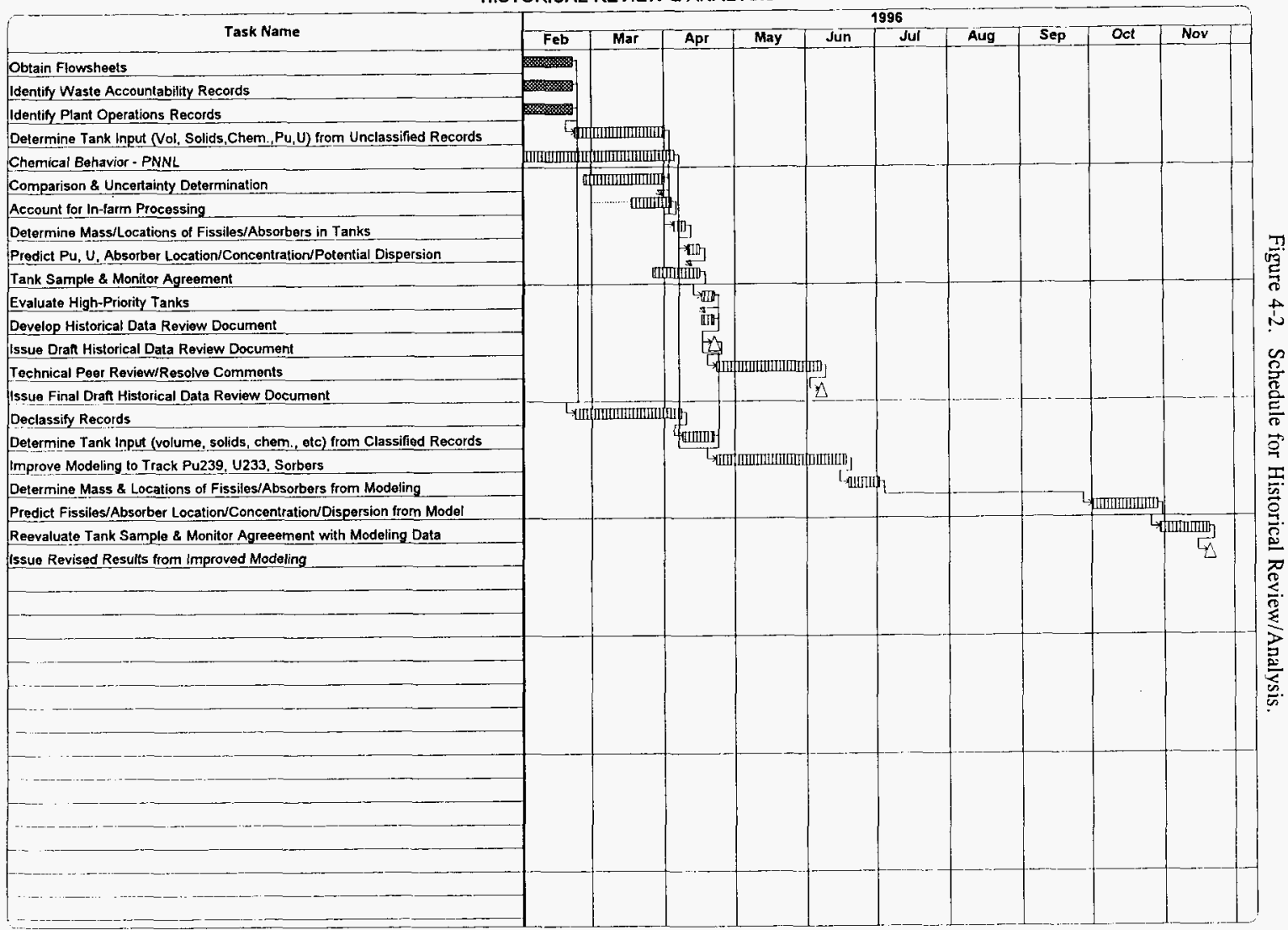

PNNL=Pacific Northwest National Laboratory $\quad$ CTBSD=Criticality Technical Basis Supporting Document 
Figure 4-3

NEUTRONICS ANALYSIS

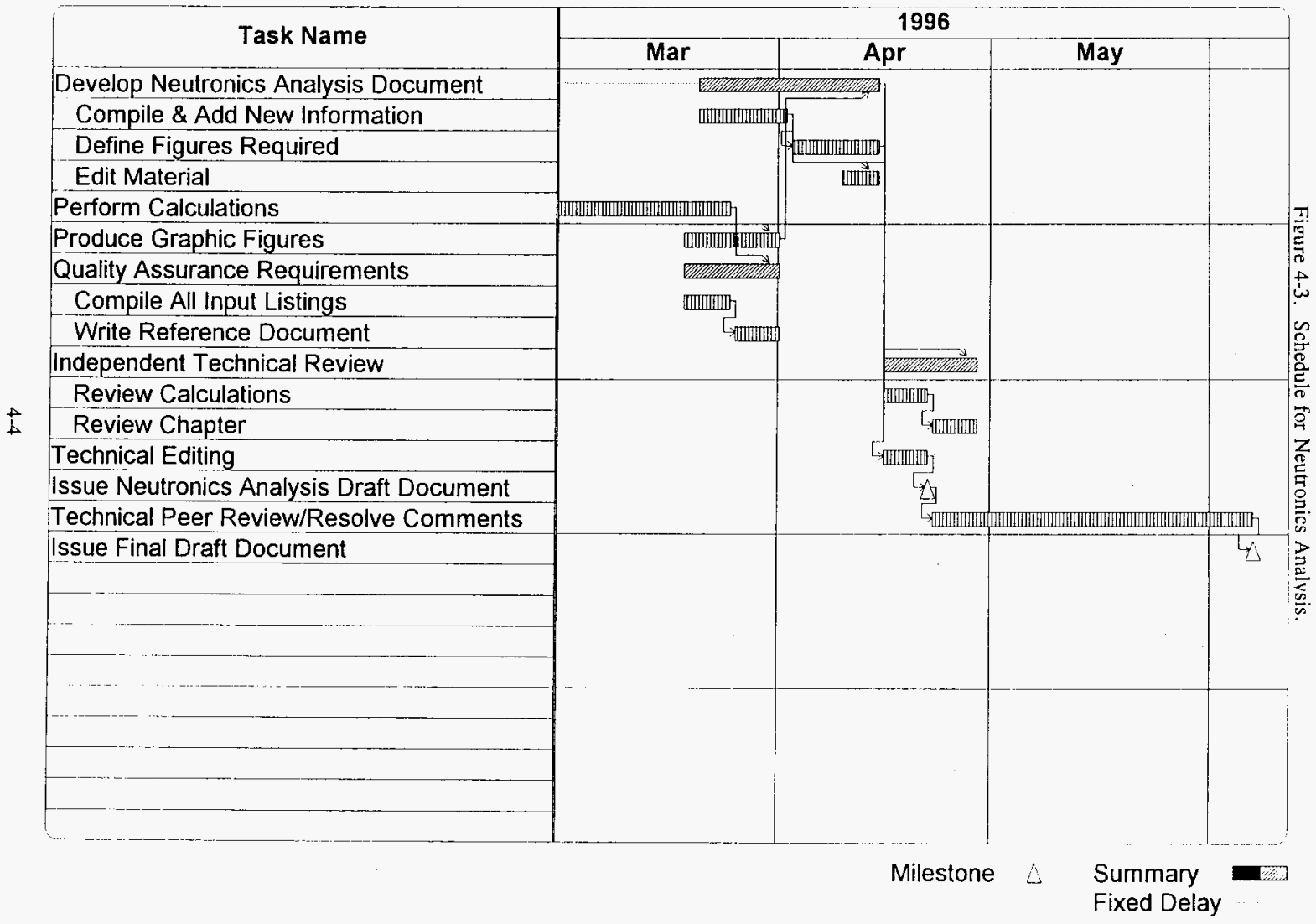


WHC-EP-0902

Revision 0

\subsection{RESOURCES PLAN}

The resource plan for this project relies on using personnel from various organizations as described. A total of $\$ 594,000$ has been identified within FY 1996 for resolution of the nuclear criticality safety issue. This funding supports activities identified in this project plan (not inclusive of Operations and Maintenance funding for ongoing criticality safety activities in support of facility operations). This funding assumes resolution of the nuclear criticality safety issue within FY 1996. Minimal funding ( $-\$ 100,000 /$ year) has been identified in the out-years (FYs 1997 to 1999) to continue to provide programmatic oversight to support continued safe operation.

The identified funding is limited to completion of technical analysis draft documents (e.g., waste partitioning/distribution and mechanistic). The identified funding is insufficient to include resolution of any technical or mechanistic issues which cannot be resolved by the technical analysis studies (i.e., does not support laboratory experimentation to demonstrate fissile material chemistry mechanisms). The project scope and identified funding are also limited to "safe storage" (i.e., do not provide a technical basis to support all future operational activities). 
WHC-EP-0902

Revision 0

This page intentionally left blank.

5-2 
WHC-EP-0902

Revision 0

\subsection{CONTROLLED ITEMS/BASELINES}

Control items/baselines for this project will be scope, schedule, and budget, as follows.

\subsection{EXPERT CRITICALITY REVIEW TEAM}

This team will be controlled to the Technical Approach outlined in Section 2.0. The primary milestone is to provide technical input to the CTBSD. Funding has been allocated to support this task.

\subsection{CTBSD TEAM}

The technical advisory consultants are controlled to the Technical Approach outlined in Section 2.0, with the milestone of delivering the final draft CTBSD to the FSAR organization on June 7,1996 , to be followed by final review and issuance. Funding for the technical advisory consultants has been allocated for this task.

The PNNL is performing the mechanistic studies/modeling, and is controlled to the Technical Approach outlined in Section 2.0. The primary milestones are the deliverables of the draft phenomenology and mechanistics document on April 22, 1996; recommendations/priorities letter on June 7, 1996; recommendations (distribution) on June 7, 1996; the technical issues response on June 28, 1996; and the bounding calculations on July 31, 1996. The budget for PNNL has been defined.

Historical review/analysis is controlled to the Technical Approach outlined in Section 2.0. The milestone for this activity is a draft document due on April 22, 1996 and a final draft of the document to be submitted to the FSAR technical editors on June 7, 1996. Funding for this activity has been defined and allocated.

Neutronics analysis is controlled to the Technical Approach in outlined in Section 2.0. The milestone for this activity is the deliverable of draft document on April 22, 1996 to be followed by submittal of the final draft of the document to the FSAR technical editors on June 7, 1996. Funding for this activity has been defined and allocated.

The FSAR is controlled through a separate activity independent of this project.

Operation/Maintenance and Control is controlled through a separate activity independent of this project. 
WHC-EP-0902

Revision 0

This page intentionally left blank. 
WHC-EP-0902

Revision 0

\subsection{REFERENCES}

Antizzo, J. V., 1995, Documentation of Agreements Reached with the Department of Energy/Richland Operations Office and the Westinghouse Hanford Company on the Path Forward for the Resolution of the Hanford Tanks Criticality Safety Issue (letter to J. E. Kinzer, U.S. Department of Energy, Richland Operations Office, July 14), U.S. Department of Energy-Headquarters, Washington, D.C.

Braun, D. J., L. D. Muhlestein, T. B. Powers, and M. D. Zentner, 1994, High-Level Waste Tank Subcriticality Safety Assessment, WHC-SD-WM-SARR-003, Rev. 0, Westinghouse Hanford Company, Richland, Washington.

Calley, H., 1995, Hanford HLW Tank Nuclear Criticality Safety Authorization Basis Meeting Minutes, October 45, U.S. Department of Energy, Richland Operations Office, Richland, Washington.

Ecology, EPA, and DOE, 1994, Hanford Federal Facility Agreement and Consent Order, as amended, Washington State Department of Ecology, U.S. Environmental Protection Agency, and U.S. Department of Energy, Olympia, Washington.

Hey, B. E., 1993, Dose Consequences for Postulated 350 MJ Hanford Site Underground Radioactive Liquid Waste Tank Criticality, WHC-SD-WM-TI-527, Rev. 0, Westinghouse Hanford Company, Richland Washington.

Hunt, J. W., 1995, Tank Safety Screening Data Quality Objective, WHC-SD-WM-SP-004, Rev. 2, Westinghouse Hanford Company, Richland Washington.

Rogers, C. A., 1994a, CSER 94-001: Criticality Safety of Single Shell Waste Storage Tanks, WHC-SD-SQA-CSA-20363, Rev. 0, Westinghouse Hanford Company, Richland, Washington.

Rogers, C. A., 1994b, CSER 94-004: Criticality Safety of Double Shell Waste Storage Tanks, WHC-SD-SQA-CSA-20368, Rev. 0, Westinghouse Hanford Company, Richland, Washington.

Vail, T. S., 1992, Upgrade Activities for the Criticality Safety Program of Hanford High-Level Radioactive Waste Tank Farm, WHC-EP-0563, Westinghouse Hanford Company, Richland, Washington.

Vail, T. S., 1994a, Waste Storage in Double Shell Tanks and Associated Equipment, CPS-T-149-00010, Rev. G-0, Westinghouse Hanford Company, Richland, Washington.

Vail, T. S., 1994b, 200 Areas Single Shell Tank Farms Criticality Prevention Specification, CPS-T-149-00011, Rev. A-0, Westinghouse Hanford Company, Richland, Washington.

Wagoner, J. D., 1995, Change to Tank Farm Authorization Basis for Criticality (letter to Dr. A. L. Trego, President of Westinghouse Hanford Company, October 10), U.S. Department of Energy, Richland Operations Office, Richland, Washington. 
WHC-EP-0902

Revision 0

This page intentionally left blank. 
Revision 0

\subsection{GLOSSARY}

\section{ABBREVIATIONS AND ACRONYMS}

CTBSD

DCRT

DOE

DOE-HQ

DST

FSAR

FY

HEPA

HLW

MUST

PNNL

RL

SST

TWRS

USQ

WHC criticality technical basis supporting document double-contained receiver tank

U.S. Department of Energy

U.S. Department of Energy-Headquarters

double-shell tank

Final Safety Analysis Report

fiscal year

high-efficiency particulate air

high-level waste

miscellaneous underground storage tank

Pacific Northwest National Laboratory

U.S. Department of Energy, Richland Operations Office single-shell tank

Tank Waste Remediation System

unresolved safety question

Westinghouse Hanford Company 
WHC-EP-0902

Revision 0

This page intentionally left blank. 
WHC-EP-0902

Revision 0

\section{DISTRIBUTION}

\section{Number of copies}

ONSITE

4

U.S. Department of Energy.

Richland Operations Office

C. L. Sohn (2)

S7-51

Hanford Technical Library

P8-55

Public Reading Room

H2-53

Westinghouse Hanford Company

H. Babad

S7-14

D. R. Bratzel (10)

57-14

L. M. Calderon

R3-01

R. J. Cash

S7-14

M. L. Cowen

A2-34

G. L. Dunford

A2-34

S. J. Eberlein

R2-12

J. W. Hagan

S7-81

J. P. Harris III

S2-48

D. W. Jeppson

L5-31

J. J. Klos

R2-54

D. S. Leach

A3-34

E. J. Lipke

S7-14

R. M. Marusich

A3-34

G. A. Meyer

S2-48

N. J. Milliken

A3-37

S. R. Nelson

B4-55

M. A. Payne

S7-84

C. A. Rogers

A3-34

A. M. Umek

H6-35

T. S. Vail

R2-54

A. E. Waltar

H0-32

Central Files

A3-88

DPC

A3-94

Pacific Northwest National Laboratory

R. J. Serne

K6-81

Dist-1 
WHC-EP-0902

Revision 0

\section{OFFSITE}

Management Strategies, Inc.

S. Wiegman

Dist-2 
WHC-EP-0902

Revision 0

This page intentionally left blank.

Dist-3 